\title{
DNA Ploidy Analysis
}

National Cancer Institute

\section{Source}

National Cancer Institute. DNA Ploidy Analysis. NCI Thesaurus. Code C18303.

A test used to measure nuclear deoxyribonucleic acid content (ploidy or multiplicity of the basic number of chromosomes) in a cell. 